\title{
Alternative Protection of Cowpea Seeds Against Callosobruchus maculat us (F.) (Coleoptera: Bruchidae) using Hermetic Storage alone or in Combination with Boscia senegalensis (Pers.) Lam ex Poir
}

\author{
D. SECK, ${ }^{1}$ G. LOGNAY, ${ }^{2}$ E. HAUBRUGE ${ }^{3}$ M. MARLIER ${ }^{2}$ and C. GASPAR ${ }^{3}$ \\ ${ }^{1}$ Institut Sénégalais de Recherches Agricoles, Laboratoire des Denrées Stockées, \\ DRCSI, B.P. 240 Saint-Louis, Sénégal, \\ ${ }^{2}$ UER Chimie Générale et Organique and \\ ${ }^{3}$ UER Zoologie Générale et Appliquée, Faculté des Sciences Agronomiques, 2-Passage des Déportés, 5-5030 \\ Gembloux, Belgium
}

\begin{abstract}
The effect of hermetic storage alone or in combination with Boscia senegalensis has been evaluated against Callosobruchus maculatus. Analysis of gas concentrations within a 7-day period indicated that $\mathrm{O}_{2}$ declined from 19.2 to $2.3 \%$ and $\mathrm{CO}_{2}$ rose from 1.2 to $22.8 \%$. Prolonged storage durations increased adult mortality, significantly increased the developmental time and induced 60-80\% reduction in the F1 progeny. The use of hermetic storage in combination with B. senegalensis fruits, at $1.2 \mathrm{~g} / 1$ (flask volume) reduced the emergence of the cowpea beetle, while 2.4-4.8 g/1 completely inhibited the production of a new generation of C. maculatus.
\end{abstract}

Key words: Callosobruchus maculatus, Vigna unguiculata, hermetic storage, Boscia senegalensis.

\section{INTRODUCTION}

Cowpea (Vigna unguiculata (L.) Walp.) seed is a cheap source of protein (Labeyrie, 1981) and is a valuable food in West African countries. Unfortunately, this crop is prone to heavy post-harvest damage by Callosobruchus maculatus (F.), commonly known as the cowpea beetle. Caswell (1973) reported on very significant losses due to C. maculatus in Nigeria. In Senegal, Seek et al. (1991) estimated that up to $90 \%$ of stored cowpeas can be damaged after 6 months. In addition, infestation by the cowpea bettle reduces the seed quality and germination ability to under $20 \%$ after 4 months (Seek, unpublished results).

The control of C. maculatus in developing countries relies heavily on the use of imported chemicals. This dependence on synthetic insecticides is not only a drain on the farmer's limited resources but may lead to many environmental and social side-effects previously well documented (Huignard, 1985; Egwuatu, 1987). On the other hand, insect resistance to one or more insecticides is a growing problem (Georghiou, 1990). This situation has increased the need for less expensive and safer strategies, among which is the use of natural products and hermetic storage.

Studies reported on hermetic storage have shown the technique to be effective against many insect species (Oxley and Wickenden, 1963; Bailey, 1965; Pattinson, 1969; Aliniazee, 1971; O'Dowd, 1971). However, the exposure time required for complete insect control may limit the use of hermetic storage alone, when a high seed quality is required. In the present work we investigated the use of hermetic storage in combination with a natural insecticide from Boscia senegalensis. B. senegalensis is a shrub which grows throughout the sahelian regions. It is distributed from Mauritania to Niger, northern Nigeria, the northwest Cameroon and across Africa to Sudan and Ethiopia (Booth and Wickens, 1988). The fruits are used as a famine food in Senegal and Sudan (Becker, 1986; Salih, Nour and Harper, 1991). The leaves are used by many farmers for grain protection. As nothing was known about the biological and chemical backgrounds of this practice, we initiated a programme focusing on these aspects. This research aimed to establish the $\mathrm{TL}_{50}$ and $\mathrm{CL}_{50}$ values to demonstrate the toxic effect of $B$. senegalensis on C. maculatus and four other stored-grain insects (Seek et al, 1993; Seek, 1994). The same authors identified that insecticidal activity of B. senegalensis is due to the liberation of volatile methylisothiocyanate (MITC) from a glucosinolate precursor contained in plant tissues. These results suggested a practical use of $B$. senegalensis in combination with hermetic storage.

\section{MATERIALS AND METHODS}

Three experiments were performed on adults and immature stages of $C$. maculatus (CM). Insects were placed in hermetic atmospheres, with exposures ranging from 1 to 7 days. The insects were reared on cowpea seeds (variety CBE5) under controlled conditions of $30 \pm 2^{\circ} \mathrm{C}$ and $80 \pm 10 \%$ r.h. The varieties, temperature and relative humidities were used for all the trials which were replicated four times. 
In the first experiment, 50 unsexed freshly emerged adults were confined in $210 \mathrm{ml}$ glass jars containing $30 \mathrm{~g}$ of healthy cowpea seeds. Seeds ( $30 \mathrm{~g}$ ) heavily infested with CM larvae (7 days old) and $30 \mathrm{~g}$ of non-infested seeds were separately placed in the same conditions.

In the second experiment, $200 \mathrm{CM}$ adults (1 day old) were confined in $850 \mathrm{ml}$ glass jars containing $121 \mathrm{~g}$ of cowpea seeds. Similarly, $121 \mathrm{~g}$ of non-infested seeds were placed in the same containers. All the jars were hermetically closed using airtight metal caps, for exposures of 1 to 7 days.

Oxygen $\left(\mathrm{O}_{2}\right)$ and carbon dioxide $\left(\mathrm{CO}_{2}\right)$ concentrations inside the flasks were measured by gas chromatograpy on a Carlo Erba Fractovap 2350 apparatus using two types of stainless steel packed columns:

$\mathrm{O}_{2}$ determination: Porapak Q (60-80 mesh), 1 m length, 0.125 inch i.d. $\mathrm{CO}_{2}$ determination: Molecular sieve $(5 \AA)$, $1.75 \mathrm{~m}$ length, 0.125 inch i.d.

In both cases, the carrier gas was argon at $30 \mathrm{ml} / \mathrm{min}$ flow rate. Injector, oven and catharometric detector (operated at $110 \mathrm{~mA}$ ) were maintained at room temperature. Gas atmospheres $(300 \mu \mathrm{l})$ were sampled at $24 \mathrm{~h}$ intervals by inserting the needle of a Hamilton $1 \mathrm{ml}$ gas-tight syringe into the jar through a rubber septum and directly injecting into the chromatograph. The chromatographic peak areas were measured automatically with a Hewlet-Packard HP 9122C integration system. Amounts of $\mathrm{O}_{2}$ and $\mathrm{CO}_{2}$ were determined (in percentages by volume) by comparing and extrapolating the data obtained with a reference gas calibrated at $5.06 \pm 0.1 \% \mathrm{CO}_{2}$ in extra pure air $\left(21 \% \mathrm{O}_{2}\right)$. After each $\mathrm{O}_{2}$ and $\mathrm{CO}_{2}$ measurement, the corresponding jar was opened to air and reclosed with a perforated lid. Immediately, it was returned to the rearing chamber until the Fl adults began to emerge. Insects were then removed daily and counted for two weeks. The duration of development was assessed and the percentage of adults which emerged was computed.

The third experiment was conducted using hermetic storage in combination with fresh $B$. senegalensis fruits. The plant material was harvested in the region of Thiès (Sénégal). A sample has been deposited at the Jardin Botanique National de Belgique (BR). Samples of $250 \mathrm{~g}$ of cowpea seeds were placed in $850 \mathrm{ml}$ glass jars and thoroughly mixed with fresh $B$. senegalensis fruits, at concentrations ranging from 1.2-4.8 g/1 (flask volume). Twenty-five unsexed CM adults (1 day old) were then placed into the flasks which were immediately sealed with hermetic caps, for an exposure of 69 days. Similarly batches of $250 \mathrm{~g}$ of untreated seeds were infested and placed in the same conditions as the treated ones. From 69 days after infestation (DAI), the F1 populations was counted in each jar and the percentage reduction of emergence was calculated in comparison with the control treatment.

\section{RESULTS}

The curves in Figs 1(A), (B) and (C) indicate the $\mathrm{O}_{2}$ depletion and $\mathrm{CO}_{2}$ build-up in the $210 \mathrm{ml}$ jars. After 1-7 days of airtight storage, $\mathrm{O}_{2}$ and $\mathrm{CO}_{2}$ concentrations in flasks containing healthy seeds were almost constant around 21 and $0 \%$, respectively (Fig. 1A). For seeds infested with larvae, $\mathrm{O}_{2}$ concentration varied from 6.5 to $0 \%$, and $\mathrm{CO}_{2}$ concentration from 19.2 to $22.8 \%$ (Fig. 1B). In the same time, gas concentrations for seeds infested with adults were 16.5 to $2.3 \%$ for $\mathrm{O}_{2}$ and 3.6 to $15.2 \%$ for $\mathrm{CO}_{2}$ (Fig. 1C). The profile of gas concentrations in $850 \mathrm{ml}$ jars is presented in Figs 1 (D) and (E). Within the 7-day period, $\mathrm{O}_{2}$ and $\mathrm{CO}_{2}$ concentrations in control jars were, respectively, 21 and $0 \%$ with little variation (Fig. ID). For seeds infested with adults, $\mathrm{O}_{2}$ concentration varied from 19.2 to $2.2 \%$ and $\mathrm{CO}_{2}$ from 1.2 to $15.1 \%$ (Fig. IE).

Data concerning the lethal effect of hermetic storage on CM indicate $91.1 \%$ adult mortality after 4 days and $100 \%$ from the 5 th day (Fig. 2).

Results from Tables 1 and 2 indicate that hermetic storage significantly prolonged the developmental duration of the cowpea beetle and induced $32-100 \%$ reduction in the population that emerged from the sealed jars compared to aerated controls.

The observation of CM daily emergence patterns indicated that prolonged airtight durations reduced the amplitude and delayed the maximum of the curves (Figs 3(A) and (B)).

Data from Table 3 summarize the effect of hermetic storage in combination with B. senegalensis on CM emergence following an initial low infestation level of 1 adult per $10 \mathrm{~g}$ of seeds. By 69 days after infestation (DAI), 763 adults emerged from the control treatments, but only 300 adults emerged in the presence of $B$. senegalensis fruits at $1.2 \mathrm{~g} / 1$ of flask volume. At 2.4 and $4.8 \mathrm{~g} / 1$ levels, CM emergence was completely inhibited up to 82 DAI. 
Fig. 1. Evolution of oxygen and carbon dioxide concentrations in hermetic jars of $210 \mathrm{ml}(\mathrm{A}, \mathrm{B}$, and $\mathrm{C})$ and 850 $m l(D$ and $E)$ containing cowpea seeds infested or not with larvae or adults of Callosobruchus maculatus.

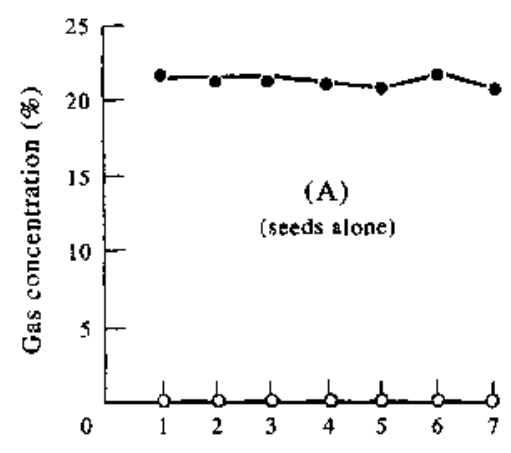

- Oxyger

- Carbon dioxide
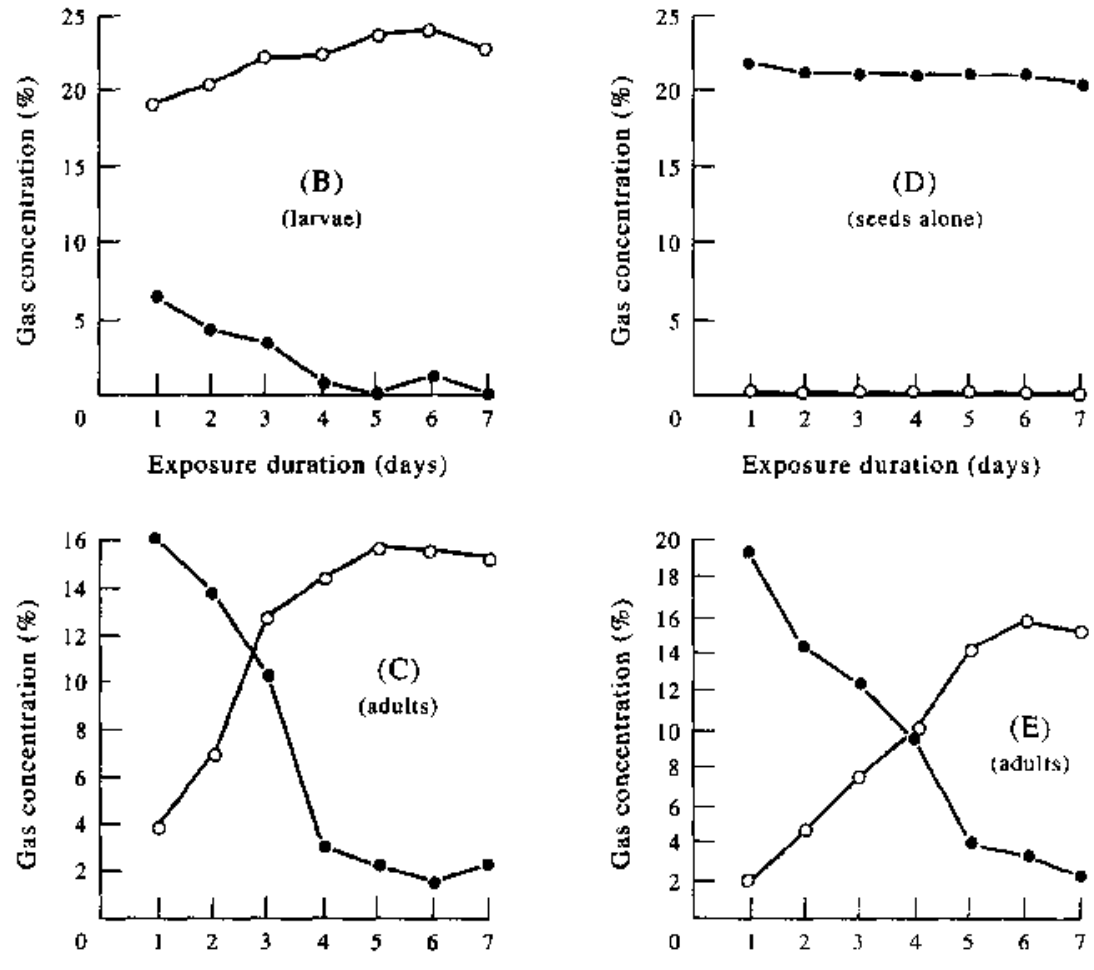

Exposure duration (days)

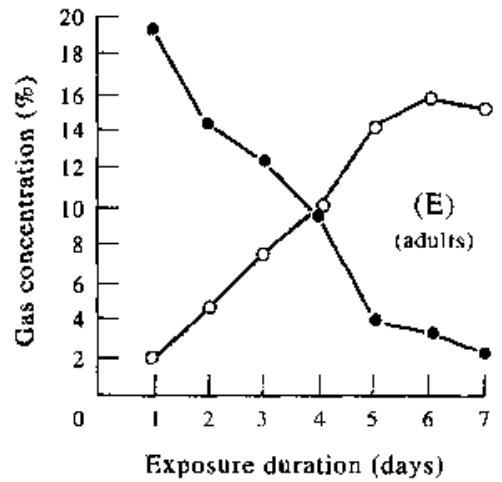

Fig. 2. Mortality of Callosobruchus maculatus adults exposed for prolonged durations in $210 \mathrm{ml}$ hermetically sealed jars.

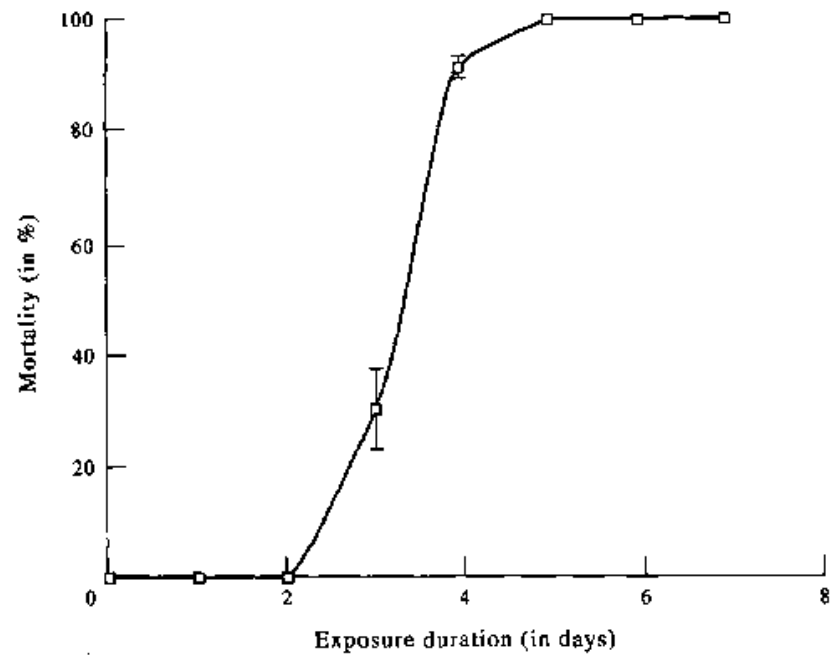


Fig. 3. Emergence pattern of Callosobruchus maculatus Fis from infested cowpea seeds placed in $210 \mathrm{ml}$ (A) or $850 \mathrm{ml}(B)$ jars and hermetically sealed for various durations.
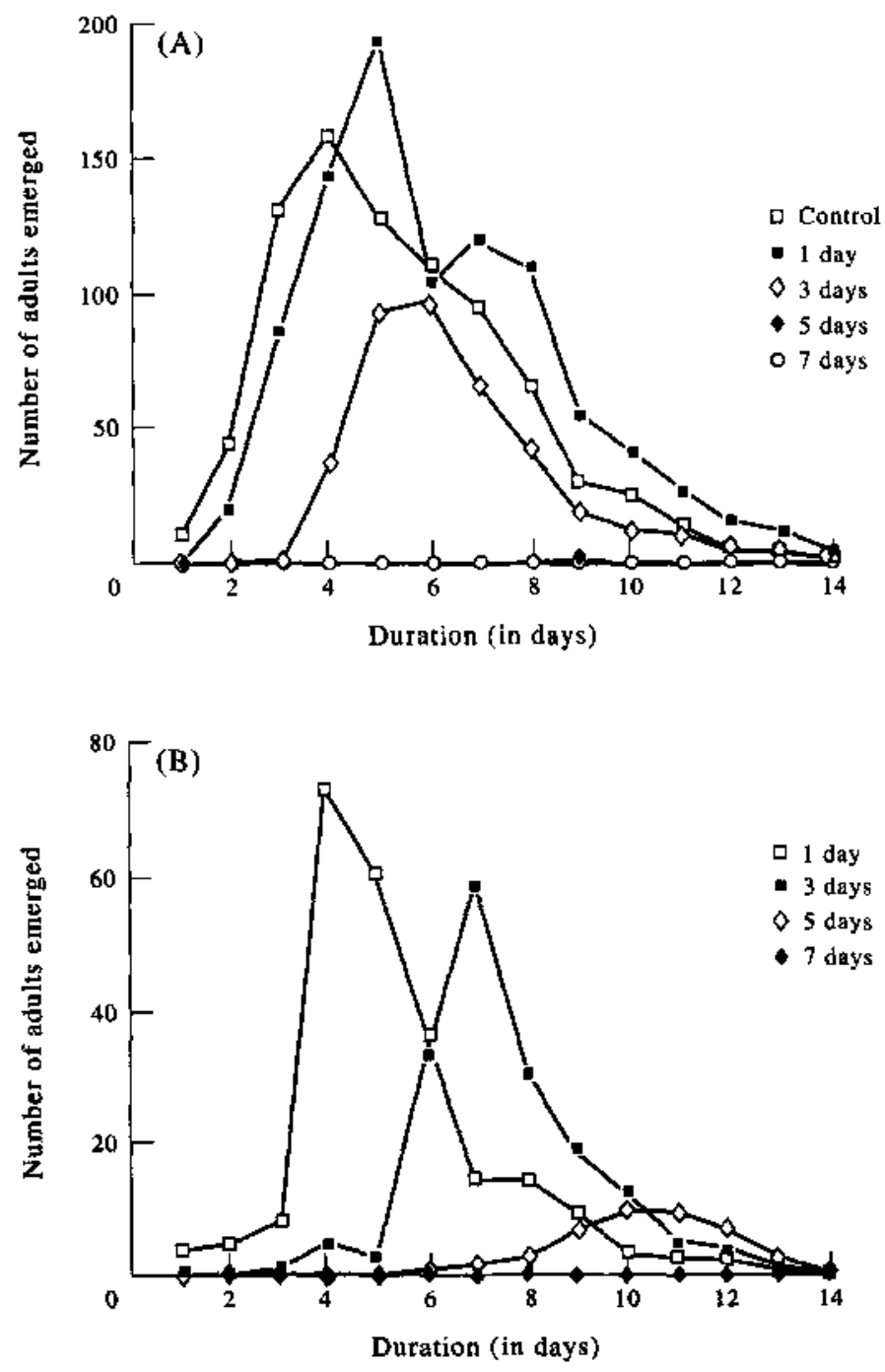

Table 1. Effect of hermetic storage in $210 \mathrm{ml}$ (B210) or $850 \mathrm{ml}$ (B850) jars on Callosobruchus maculatus Fl development following exposure of adults

\begin{tabular}{llcllll}
\hline & \multicolumn{3}{c}{$\mathrm{B} 210$} & & $\mathrm{~B} 850$ \\
$\begin{array}{c}\text { Exposure duration } \\
\text { (days) }\end{array}$ & $\mathrm{DD}^{*}$ & $\mathrm{nE}^{\mathrm{b}}$ & $\mathrm{PR}$ & $\mathrm{DD}^{\mathrm{a}}$ & $\mathrm{nE}^{\mathrm{b}}$ & $\mathrm{PR}^{\mathrm{C}}$ \\
\hline 0 (control) & 18 & 829 & - & 20 & 2729 & - \\
1 & 18 & 932 & 0 & 20 & 1846 & 32 \\
2 & 18 & 858 & 0 & 20 & 1604 & 41 \\
3 & 20 & 392 & 53 & 21 & 1241 & 55 \\
4 & 23 & 56 & 93 & 21 & 1103 & 60 \\
5 & 26 & 2 & near 100 & 22 & 822 & 70 \\
6 & 24 & 3 & near 100 & 24 & 52 & 98 \\
7 & - & 0 & 100 & 26 & 71 & 97 \\
\hline
\end{tabular}

${ }^{\mathrm{a}}$ Developmental duration (in days). ${ }^{\mathrm{b}}$ Total number of adults emerged.

${ }^{\mathrm{c}}$ Percentage reduction in emergence (compared to control treatment) 
Table 2. Effect of hermetic storage in $210 \mathrm{ml}$ jars on Callosobruchus maculatus F1 emergence following exposure to larvae

\begin{tabular}{llll}
\hline \multicolumn{2}{c}{ Exposure duration (days) } & \multicolumn{2}{c}{$\mathrm{nE}^{\mathrm{a}}$} \\
\hline 0 (control) & 554 & - \\
1 & 239 & 56.9 \\
2 & 229 & 58.7 \\
3 & 177 & 68.1 \\
4 & 124 & 77.6 \\
5 & 45 & 91.9 \\
6 & 48 & 91.3 \\
7 & 1 & near 100
\end{tabular}

${ }^{\mathrm{a}}$ Total number of adults emerged. ${ }^{b}$ Percentage reduction in emergence (compared to control treatment).

Table 3. Effect of Boscia senegalensis in combination with hermetic storage on Callosobruchus maculatus F1 emergence

\begin{tabular}{llll}
\hline Treatment & \multicolumn{3}{l}{ Cumulative numbers of adults emerged (\% reduction) } \\
\cline { 2 - 4 } & 69 DAP & 72 DAP & 82 DAP \\
\hline Control & $190.8 \pm 76.1$ & $208.8 \pm 77.7$ & $306.8 \pm 149.7$ \\
& $(-)$ & $(-)$ & $(-)$ \\
$1.2 \mathrm{~g} / 1$ & $75.0 \pm 16.5$ & $76.3 \pm 16.5$ & $96.0 \pm 32.2$ \\
& $(60.7)$ & $(63.5)$ & $(68.7)$ \\
$2.4 \mathrm{~g} / 1$ & $0.0 \pm 0.0$ & $0.0 \pm 0.0$ & $0.0 \pm 0.0$ \\
& $(100)$ & $(100)$ & $(100)$ \\
$4.8 \mathrm{~g} / 1$ & $0.0 \pm 0.0$ & $0.0 \pm 0.0$ & $0.0 \pm 0.0$ \\
& $(100)$ & $(100)$ & $(100)$ \\
\hline
\end{tabular}

${ }^{a}$ Days after infestation.

\section{DISCUSSION}

Results obtained from the three experiments clearly demonstrate the effectiveness of hermetic storage alone or in combination with $B$. senegalensis. Studies on hermetic storage alone, using jars of different volumes, indicated a gradual depletion of $\mathrm{O}_{2}$ and an increase of $\mathrm{CO}_{2}$ concentrations in relation to the duration of storage, the insect stage and the level of infestation. These results are in agreement with those of many other authors (Williams and Wilbur, 1968, 1969; Aliniazee, 1971; Ofuya and Reichmuth, 1994).

Under our experimental conditions, hermetic storage alone at a high infestation level gave near or complete disinfestation after 5 to 7 days. Subsequently, the duration of development was significantly extended and the emergence of a new generation was reduced or completely inhibited.

Storage of comparatively lightly infested cowpea samples (1 insect/10 g seeds), mixed with fresh ground fruits of B. senegalensis (at the level of $2.4 \mathrm{~g} / 1$ ) in hermetically sealed containers, achieved total control of both infestation and damage by the cowpea beetle.

These results give evidence indicating a potential use of the locally available tree $B$. senegalensis in combination with hermetic storage, as an alternative to synthetic pesticides in the sahelian zone of Africa.

Acknowledgements-We appreciated the assistance of Drs M. Dieye and A. N'Diaye, Miss R. Diouf, M. M. G. Delimme, Z. Miest and D. Trisman. Sincere thanks are due to Mrs M. Fall and A. Ly who typed the manuscript. 
Published in: Journal of stored products research (1996), vol. 32, iss. 1, pp. 39-44

Status: Postprint (Author's version)

\section{REFERENCES}

Aliniazee M. T. (1971) The effect of carbon dioxide gas alone or in combinations on the mortality of Tribolium castaneum (Herbst) and T confusion du Val (Coleoptera, Tenebrionidae). Journal of Stored Products Research 7, 243-252.

Bailey S. W. (1965) Airtight storage of grain; its effect on insect pests—Rhyzopertha dominica (F.) and some other Coleoptera that infest stored grain. Journal of Stored Products Research 1, 25-33.

Becker B. (1986) Wild plants for human nutrition in the sahelian zone. Journal of Arid Environment 11, 61-64.

Booth F. E. M. and Wickens G. E. (1988) Non-timber uses of selected arid zone trees and shrub in Africa. F. A. O. Conservation Guide 19, 176.

Caswell G. H. (1973) The impact of infestation on commodities. Tropical Stored Products Information 25, 19.

Egwuatu R. I. (1987) Current status of conventional insecticides in the management of stored-product insect pests in the tropics. Insect Science and its Application 8, 695-701.

Georghiou P. G. (1990) Overview of Insecticide Resistance (Edited by Green M. B., Lebaron H. M. and Moberg W. K.). ACS Symposium Series 421, pp. 19-41. American Chemical Society, Washington, DC.

Huignard J. (1985) Importance des pertes dues aux insectes ravageurs des graines: problèmes posés par la conservation des légumineuses alimentaires sources de protéines végétales. Cahiers du nutrition et de diététique XX, 193-199.

Labeyrie V. (1981) Vaincre la carence protéique par le développement de légumineuses alimentaires et al protection de leurs récoltes contre les bruches. Food and Nutrition Bulletin 3, 24-38.

O'Dowd E. T. (1971) Hermetic storage of cowpea (Vigna unguiculata (L.) Walp.) in small granaries, silos and pitts in Nigeria. Sumaru Miscellanous Paper 31.

Ofuya T. I. and Reichmuth C. (1994) Effect of level of seed infestation on mortality of larvae and pupae of Callosobruchus maculatus (F.) in some controlled atmospheres. Journal of Stored Products Research 30, 75-78.

Oxley T. A. and Wickenden G. (1963) The effect of restricted air supply on some insects which infest grain. Annals of Applied Biology 51 , 313-324.

Pattinson M. I. (1969) Description d'une méthode de stockage de grains à la ferme par un procédé de conservation hermétique en utilisant des bidons métalliques. Rapport du projet F. A. O. de l'institut de Technologie Alimentaire de Dakar (Sénégal), 5 pp.

Salih O. M., Nour A. M. and Harper D. B. (1991) Chemical and nutritional composition of two famine food sources used in Sudan, mukheit (Boscia senegalensis) and maikah (Doberaoxbburghi). Journal of the Science of Food and Agriculture 57, 367-377.

Seek D. (1994) Development of alternative control methods against the main stored-grain insects in Senegal using indigenous plants. Ph.D. thesis (in French), Gembloux, Faculté des Sciences agronomiques.

Seek D., Sidibé B., Haubruge E. and Gaspar C. (1991) La protection des stocks de niébe (Vigna unguiculata (L.) Walp.) en milieu rural: utilisation de différentes formulations à base de neem (Azadirachta indica A. Juss.) provenant du Sénégal. Medlingen an der Faculteit Landbouwkundige Universiliet Cent, pp. 1217-1224.

Seek D., Lognay G., Haubruge E., Wathelet J.-P., Marlier M., Gaspar C. and Severin M. (1993) Biological activity of the shrub Boscia senegalensis (Pers.) Lam. ex Poir. (Capparaceae) on stored-grain insects. Journal of Chemical Ecology 19, $377-389$.

Williams J. H. and Wilbur D. A. (1968) Respiratory environments of grain-infesting weevils. I. Comparison of culture-jar and laboratory rearing atmospheres. Journal of Economic Entomology 61, 345-348.

Williams J. H. and Wilbur D. A. (1989) Respiratory environments of grain-infesting weevils. I. Comparison of respiratory populations of three species of grain weevils. Journal of Economic Entomology 62, 693-697. 